BHUMI: Jurnal Agraria dan Pertanahan

Received: March 28, 2019; Reviewed: April 7, 2019; Accepted: April 28, 2019.

To cite this article: Pujiriyani, DW, Soetarto, E, Santosa, DA, Agusta, I 2019, 'Tekanan populasi, kepadatan agraris, dan ketersediaan lahan pada komunitas petani', Bhumi, Jurnal Agraria dan Pertanahan, vol. 5, no. 1, hlm. 42-53.

DOI: http://dx.doi.org/10.31292/jb.v5i1.318

Copyright: @2019 Dwi Wulan Pujiriyani dkk. All articles published in Jurnal Bhumi are licensed under a Creative Commons Attribution-ShareAlike 4.o International license.

\title{
TEKANAN POPULASI, KEPADATAN AGRARIS, DAN KETERSEDIAAN LAHAN PADA KOMUNITAS PETANI
}

\section{POPULATION PRESSURE, AGRARIAN DENSITY, AND LAND AVAILABILITY IN THE PEASANT COMMUNITY}

\author{
Dwi Wulan Pujiriyani*, Endriatmo Soetarto** \\ Dwi Andreas Santosa ${ }^{* * *}$, Ivanovich Agusta ${ }^{* *}$ \\ *Sekolah Tinggi Pertanahan Nasional \\ **Fakultas Ekologi Manusia, Institut Pertanian Bogor \\ ***Fakultas Pertanian, Institut Pertanian Bogor \\ *Email: lucia_wulan@yahoo.com
}

\begin{abstract}
Population density is a serious problem for the existence of the peasant community and its agricultural landscape. In this situation, deagrarianization becomes a necessity because the economies scale of farming are becoming smaller and not profitable for peasants. This paper aims to analyze the community's strategy in maintaining its agrarian landscape. Data for this study were obtained through community case study method. Live in strategy is done for 2.5 months to deepen understanding at the community. The results showed that the peasant community was actively defend not to get out from agriculture. Expansion by increasing land ownership and reducing population numbers are the two main strategies. This strategy allows the ratio of agrarian landscape and agrarian density not to make the younger generation lose the opportunity to own agricultural land. Optimism to increase ownership of agricultural land for the younger generation is done by buying agricultural land from those who are not interested in pursuing agriculture.
\end{abstract}

Keywords: land ownership, agriculture, deagrarianization, community strategy

Intisari: Kepadatan penduduk merupakan masalah serius bagi eksistensi komunitas petani dan bentang agrarianya. Dalam situasi serupa ini, deagrarianisasi menjadi sebuah keniscayaan karena skala ekonomi usaha tani menjadi semakin kecil dan tidak menguntungkan bagi petani. Tulisan ini bertujuan untuk menganalisis strategi komunitas dalam mempertahankan bentang agrarianya. Data untuk penelitian ini diperoleh melalui metode studi kasus komunitas. Pendalaman di tingkat komunitas dilakukan dengan live in selama 2,5 bulan. Hasil penelitian menunjukkan bahwa komunitas petani secara aktif berstrategi untuk tidak keluar dari pertanian. Ekspansi dengan menambah kepemilikan lahan dan mengurangi jumlah populasi merupakan dua strategi yang utama. Strategi ini memungkinkan rasio bentang agraria dan kepadatan agraris tidak membuat generasi yang lebih muda kehilangan kesempatan untuk memiliki lahan pertanian. Optimisme menambah kepemilikan lahan pertanian bagi generasi yang lebih muda dilakukan dengan cara membeli lahan pertanian dari mereka yang sudah tidak berminat menekuni pertanian.

Kata Kunci: kepemilikan lahan, pertanian, deagrarianisasi, strategi komunitas 


\section{A. Pendahuluan}

Laju pertumbuhan penduduk dan daya dukungan lingkungan terutama lahan pertanian merupakan salah satu aspek penting yang menopang pangan. Pertambahan penduduk menjadi permasalahan serius bagi kelangsungan hidup. Daya dukung lahan akan semakin kecil akibat tingginya tingkat pertumbuhan penduduk. Lahan pertanian sebagai penyedia pangan, akan terus menurun sejalan dengan laju pertumbuhan penduduk (Rohman 2015).

Indonesia merupakan salah satu negara yang mengalami problem demografi. Mengacu pada laporan PBB (United Nations) tahun 2015, Indonesia termasuk ke dalam satu dari 9 negara yang memiliki pertumbuhan populasi tertinggi. PBB memproyeksikan bahwa di tahun 2050, populasi dunia akan mencapai 9,7 milyar jiwa dengan konsentrasi pertumbuhan tertinggi di 9 negara yaitu: India, Pakistan, Republik Demokratik Kongo, Etiopia, Tanzania, Amerika, Indonesia, dan Uganda. Jika mengacu pada Data BPS tahun 2018, terlihat bahwa jumlah penduduk Indonesia sudah mencapai 261,9 juta jiwa.

Ciri umum banyak negara berkembang adalah kelebihan penduduk agraris yaitu terdapatnya surplus tenaga kerja manusia dibanding dengan tersedianya tanah pertanian. Hal inilah yang menyebabkan penduduk desa terus menerus memadati tanah yang ada. Sebagaimana disebutkan Tauchid (2009), manusia tidak dapat hidup tanpa tanah, sebaliknya tanah juga tidak dapat menghasilkan makanan jika tidak ada manusia yang mengolahnya. Ketika jumlah penduduk terus meningkat sementara luas lahan dan produktifitasnya tetap, maka goncangan terhadap eksistensi kehidupan penduduk terutama penduduk yang ketergantungannya terhadap lahan sangat tinggi, tidak dapat terhindarkan (Ruhimat 2015).

Mengacu pada Tjondronegoro dan Wiradi (2008), desa-desa Jawa menurut tradisi sudah terbiasa dengan kepadatan yang tinggi dan mampu menyesuaikan diri pada kelebihan penduduk secara terus menerus. Kepadatan lokal atau kelebihan penduduk yaitu perbandingan lokal antara jumlah penduduk dengan luas tanah yang dibu- tuhkan untuk mencukupi makanan pokoknya sudah menjadi pola ekologi yang sangat umum di Jawa jauh sebelum Belanda datang. Sejak dulu, pedesaan di Jawa telah mengenal gejala penduduk yang tidak memiliki tanah yang hidup dari memburuh tani, sebagai petani penggarap atau berdagang. Pada jaman penjajahan (1913), rata-rata kepemilikan oleh penduduk di Jawa kurang dari o,5 hektar, bahkan ada beberapa tempat yang hanya 0,3 ha dan di beberapa daerah lainnya o,8 ha (Tauchid, 2009). Selama 40 tahun terakhir (19632003), Bachriadi dan Wiradi (2011) mencatat bahwa rata-rata penguasaan lahan petani di Jawa sekitar o,45 hektar. Situasi ini menunjukkan bahwa selama 4o tahun terakhir, kelas petani gurem mendominasi mayoritas rumah tangga petani di Indonesia.

Saat ini, situasi di Jawa menunjukkan bahwa perluasaan lahan pertanian sudah sulit untuk dilakukan. Tekanan penduduk merupakan persoalan yang penting yang sedang dihadapi pulau dengan penduduk terpadat di Indonesia ini. Tekanan penduduk adalah aneka kesulitan penduduk dalam memperjuangkan hidupnya akibat kepadatan penduduk di suatu wilayah tidak diikuti oleh kemampuan wilayah tersebut dalam mendukung dan menyediakan kehidupan penduduk. Molle (2003) menyebutkan bahwa fragmentasi tanah sangat kuat terjadi dalam sistem agraria Asia yang dicirikan oleh tingginya jumlah pertanian skala kecil dan pertumbuhan demografi yang sangat tinggi. Hal ini jelas terlihat pada rasio petani dan ketersediaan lahan pertanianyang sulit mencapai titik seimbang/ ideal. Dalam konteks penguasaan lahan pertanian, Geertz (1976) menegaskan bahwa 0,5 hektar merupakan batasan minimal lahan pertanian untuk petani di Jawa. Lahan pertanian dengan luasan o,5 hektar berada di atas lapisan marjinal atau lapisan terbawah petani dan berada pada batas petani lapisan atas atau petani komersial (> 5 hektar).

Studi mengenai tekanan penduduk terhadap lahan pertanian sudah banyak dilakukan sebelumnya. Studi yang dilakukan Muyanga \& Jaine (2014) melihat tekanan penduduk sebagai determinan penting yang menyebabkan petani memilih untuk meninggalkan pertanian. Dalam konteks ini rumah tangga di wilayah yang akses terhadap tanahnya 
rendah, cenderung akan memilih untuk bermigrasi ke area dimana mereka bisa memperoleh akses tanah yang lebih baik. Kelangkaan sumberdaya mendorong orang-orang untuk bermigrasi.

Sementara itu studi lain mengenai tekanan penduduk terhadap lahan pertanian lebih mengaitkannya dengan inefisiensi pengelolaan pertanian. Hal ini dapat dilihat pada studi yang dilakukan Rickert-Gilbert et al (2014), Manjunatha et al (2014), Mellor (2014), serta Heady et al (2014). RickertGilbert et al (2014) dalam studinya di Malawi, menyebutkan bahwa wilayah dengan tingkat kepadatan populasi yang tinggi mengindikasikan luasan tanah pertanian yang lebih sempit, rata-rata upah pertanian yang lebih rendah, dan harga tanaman pangan yang lebih tinggi. Populasi yang meningkat tidak memungkinkan petani untuk meningkatkan nilai hasil panen per hektar. Rumah tangga dengan tingkat kepadatan populasi yang tinggi cenderung mengandalkan pendapatan dari sumber non pertanian. Pertumbuhan populasi menyebabkan plot lahan menjadi semakin kecil karena diberikan dari orang tua kepada anak-anaknya. Ketika populasi bertambah, tanah menjadi langka. Studi Gilbert ini mendukung studi Latrufe \& Piet (2013) yang menyebutkan bahwa berkurangnya lahan pertanian menyebabkan biaya produksi semakin meningkat, sehingga mengurangi pendapatan pertanian yang bisa diperoleh petani.

Dari studi mengenai tekanan penduduk terhadap lahan pertanian, belum ditemukan studi yang melihat dari aspek kemampuan komunitas dalam mempertahankan bentang agrarianya. Studi ini lebih lanjut akan menganalisis mengenai strategi komunitas dan kemampuan komunitas untuk bertahan dalam bentang agrarianya. Pilihan untuk tetap bertahan di pertanian merupakan sebuah anomali dari deagrarianisasi yang sedang terjadi pada berbagai wilayah pedesaan di dunia (Rigg 2001; Bryceson 2002). Konsep 'strategi' dalam hal ini merupakan sebuah penegasan bahwa komunitas petani merupakan aktor sosial yang aktif dan bukan korban serta resipien yang pasif. Petani memiliki agensi yang memungkinkannya untuk merespon berbagai persoalan yang dihadapinya (Long 2001; Ploeg 2008). Strategi komunitas merupakan wujud empirik dari kapasitas internal atau keswadayaan komunitas.

Metode yang digunakan dalam penelitian ini adalah metode studi kasus komunitas. Mengacu pada Berg (2001), studi kasus komunitas merupakan strategi pengumpulan informasi secara sistematis mengenai sebuah komunitas tertentu untuk memberikan pemahaman dan penyadaran bagi peneliti mengenai apa yang sedang terjadi di dalam komunitas, apa dan bagaimana ini bisa terjadi dan siapa di antara anggota-anggota di dalam komunitas yang mengambil bagian di dalam aktivitas tersebut serta apa saja kekuatan sosial yang mengikat anggota-anggota komunitas ini.

Sumber data dalam penelitian ini terdiri dari data primer dan data sekunder. Data primer diperoleh melalui observasi dan wawancara mendalam. Sementara itu data sekunder diperoleh melalui data statistik yang dikeluarkan Badan Pusat Statistik, Pusat Data dan Sistem Informasi Kementerian Pertanian, serta data kependudukan dan dokumen pajak dari desa. Informan utama dalam penelitian ini adalah petani dari generasi kedua dan generasi ketiga di dalam komunitas. Perspektif emik dilakukan dalam penelitian ini dengan melakukan pembacaan jarak dekat (close reading) melalui pendekatan etnografi. Penelitian lapangan (live in) dilakukan pada pertengahan tahun 2017 untuk kemudian melakukan kunjungan ulang pada awal tahun 2018 dan beberapa pembaruan data melalui wawancara jarak jauh dengan informan pada akhir tahun 2018 dan awal tahun 2019.

\section{B. Situasi Pertanian dan Problem}

\section{Demografis: Konteks Makro dan Meso}

Pertanian merupakan salah satu sektor unggulan di Jawa Tengah selain sektor perkebunan. Hal ini ditopang dengan tingkat kesuburan yang relatif baik. Meskipun demikian, pertanian di Jawa Tengah tidak sepenuhnya menunjukkan situasi yang menggembirakan. Laporan Sensus Pertanian Tahun 2013 dari BPS Provinsi Jawa Tengah menunjukkan bahwa jumlah rumah tangga usaha pertanian di wilayah ini mengalami penurunan sebesar $25,65 \%$ dari 5.770.801 menjadi 4.290.619. Dari jumlah rumah tangga pertanian yang ada di Jawa Tengah, 
99\% (4.262.608) merupakan rumah tangga petani pengguna lahan dan hanya $1 \%$ (28.011) yang merupakan rumah tangga petani bukan pengguna lahan.

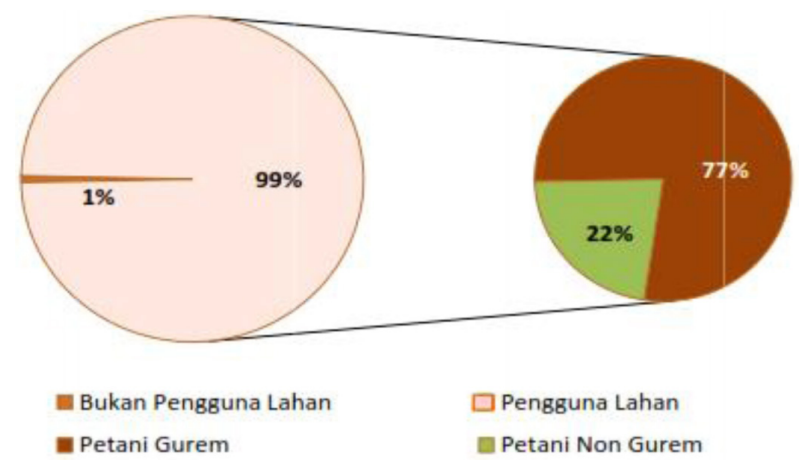

Gambar 1. Rumah Tangga Usaha Pertanian di Jawa Tengah.

Sumber: BPS Provinsi Jawa Tengah, 2013.

Meskipun sebagian besar termasuk rumah tangga pengguna lahan, rumah tangga usaha pertanian di Jawa Tengah 77,7 \%-nya (3.312.235) didominasi oleh rumah tangga petani gurem yaitu rumah tangga usaha pertanian yang menguasai

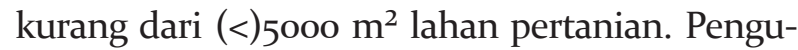
asaan terluas tercatat sebesar "30.000 $\mathrm{m}^{2}$, hanya ditemukan pada 20.140 rumah tangga atau sekitar 0,004\%. Hanya 22,3\% (950.373) rumah tangga yang bukan termasuk kategori rumah tangga petani gurem. Hal ini menunjukkan bahwa skala usaha rumah tangga petani Jawa Tengah termasuk kecil. Tabel 1 menunjukan perbandingan luas lahan yang dikuasai rumah tangga petani pada tahun 2003 dan 2013. Penguasaan lahan yang paling banyak dapat dijumpai pada golongan luasan $2000 \mathrm{~m}^{2}-4.999 \mathrm{~m}^{2}$.

Tabel 1. Jumlah Rumah Tangga Usaha Pertanian di Jawa Tengah Menurut Golongan Luas Lahan yang Dikuasai

\begin{tabular}{clll}
\hline No. & Golongan Luas Lahan $\left(\mathrm{m}^{2}\right)$ & Tahun 2003 & Tahun 2013 \\
\hline 1. & $<1000$ & 2.187 .774 & 865.987 \\
2. & $1.000-1.999$ & 912.343 & 921.001 \\
3. & $2.000-4.999$ & 1.602 .712 & 1.553 .181 \\
4. & $5.000-9.999$ & 759.977 & 681.252 \\
5. & $10.000-19.999$ & 247.838 & 214.041 \\
6. & $20.000-29.999$ & 39.684 & 35.017 \\
7. & $=30.000$ & 20.473 & 20.140 \\
\hline \multicolumn{7}{r}{} & Jumlah & 5.770 .801 & 4.290 .619 \\
\hline
\end{tabular}

Sumber: BPS Provinsi Jawa Tengah, 2013.
Skala usaha rumah tangga petani di Jawa Tengah yang relatif kecil sejalan dengan fakta bahwa Jawa Tengah juga menyimpan persoalan demografis akibat tekanan kependudukan. Situasi ini menyebabkan ketersediaan lahan pertanian di wilayah ini dapat menjadi kendala yang besar dalam waktu mendatang. Data BPS Tahun 2018 menunjukkan bahwa jumlah penduduk di Jawa Tengah berada pada posisi ke 3 setelah Jawa Barat 48.037,6 ribu jiwa dan Jawa Timur 39.293 ribu jiwa (Lihat Gambar 2). Jumlah penduduk di Jawa Tengah tercatat sebesar 34.257,9 ribu jiwa dengan kepadatan penduduknya 1.053 jiwa $/ \mathrm{km}^{2}$.

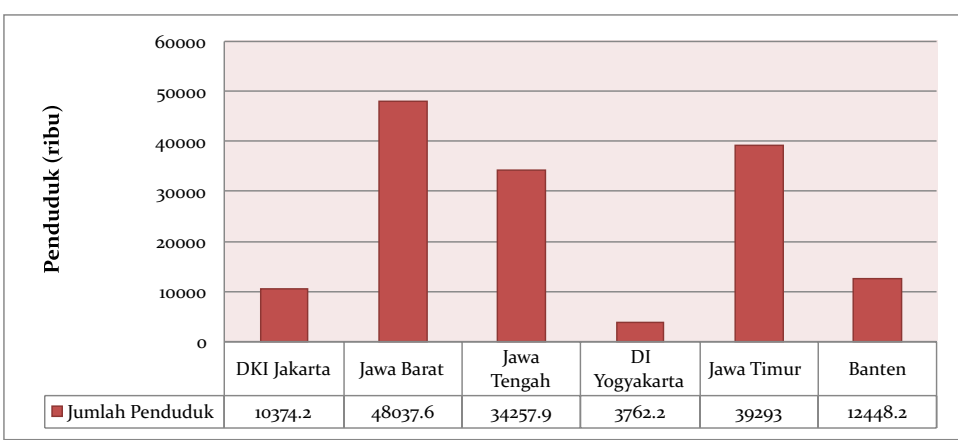

Gambar 2. Jumlah Penduduk pada Enam Provinsi di Pulau Jawa. Sumber: BPS, 2018.

Jumlah penduduk yang besar dan laju pembangunan mendorong semakin meningkatnya konversi lahan pertanian di Pulau Jawa. Effendi dan Asmara (2014) mencatat bahwa Koridor Ekonomi Jawa merupakan pusat kegiatan nasional dan sumber pendapatan nasional, sehingga meniscayakan berbagai peruntukan pembangunan terjadi di wilayah ini. Konversi lahan sawah terjadi karena adanya desakan untuk memenuhi kebutuhan pendudukyang semakin bertambah jumlahnya seperti pemukiman, industri maupun prasarana dengan tujuan memperluas kegiatan ekonomi.

Situasi Jawa Tengah mengacu pada Statistik Lahan Pertanian Tahun 2012-2017 menunjukkan bahwa telah terjadi penurunan yang nyata pada luas lahan pertaniannya, terutama pada kategori lahan sawah, baik sawah irigasi maupun sawah non irigasi. Gambar 3 menunjukan bahwa selama 6 tahun terakhir (2012-2017) telah terjadi penurunan lahan persawahan dengan total luasan 150.100,06 hektar. Penurunan tertinggi terjadi pada tahun 2013 seluas 148.871,o6 hektar, dari 1.101.851,06 hektar 
pada tahun 2012 menjadi 952.980 hektar di tahun 2013. Sementara itu pada dua tahun terakhir yaitu dari tahun 2016 ke tahun 2017 terjadi penurunan lahan persawahan seluas 11.914 hektar dari 963.665 hektar pada tahun 2016 menjadi 951.751 hektar pada tahun 2017.

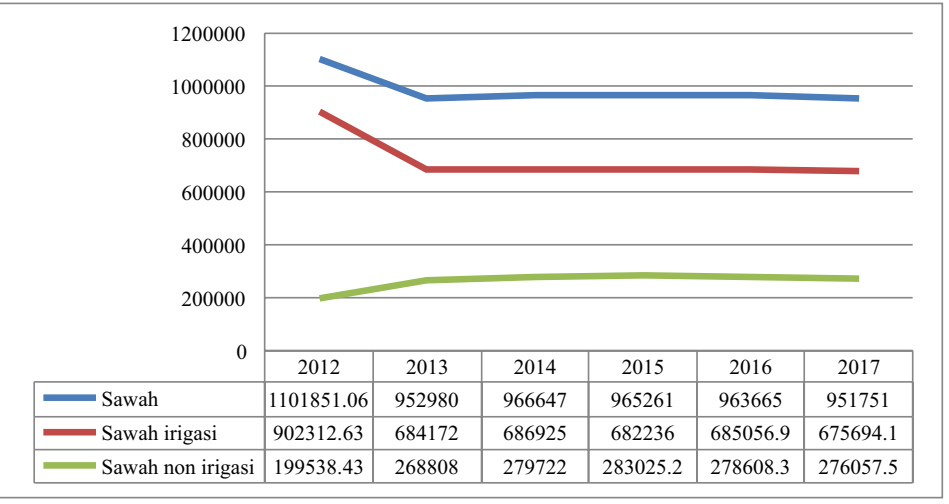

Gambar 3. Perbandingan Luas Sawah, Sawah Irigasi, dan Sawah Non Irigasi di Jawa Tengah. Sumber: Pusdatin Sekjen Kementerian Pertanian, 2018.

Sebagaimana ditambahkan Ashari (2003), intensitas konflik dalam pemanfaatan lahan di Pulau Jawa memang lebih tinggi dibandingkan dengan pulau-pulau lain karena perluasan lahanlahan pertanian sudah sangat terbatas peluangnya. Dinamika pembangunan yang terjadi di Jawa menunjukkan transformasi struktur ekonomi dan demografi yang pada akhir tahun 1980-an sudah ditandai dengan fenomena alih fungsi (konversi) lahan sawah ke penggunaan non pertanian secara masif di pulau ini. Tuntutan kebutuhan lahan untuk pengembangan sektor industri, jasa, dan perumahan semakin meningkat dan tidak mungkin dihindari sejalan dengan pertumbuhan ekonomi wilayah.

Melihat konteks makro tekanan penduduk terhadap lahan pertanian yang terjadi di Jawa Tengah, penting untuk melihat situasi yang terjadi di tingkat meso. Pada konteks mesoyaitu di wilayah Kabupaten Pati, dari aspek demografi wilayah ini merupakan wilayah yang cukup padat. Data BPS Tahun 2018 menunjukkan bahwa jumlah penduduk di Kabupaten Pati berjumlah 1.246.691 jiwa yang terdiri dari 603.907 laki-laki dan 642.784 perempuan. Dengan luas wilayah 1503,68 km² kepadatan penduduk di Kabupaten Pati termasuk cukup tinggi yaitu 836 jiwa $/ \mathrm{km}^{2}$. Mengacu pada penelitian Rohman (2015), tekanan agraris di Kabupaten Pati yang sudah mencapai 1,1 pada tahun 2010, dan diproyeksikan menjadi 1,2 pada tahun 2020, menunjukan bahwa jumlah penduduk di Kabupaten Pati sudah melampaui daya dukung wilayah. Tekanan serupa ini menyebabkan dorongan untuk berpindah ke daerah lain/pergi ke kota atau mencari pekerjaan baru di luar sektor pertanian. Tekanan penduduk menunjukkan sulitnya memperjuangkan hidup akibat kepadatan penduduk di suatu wilayah yang tidak diikuti oleh kemampuan wilayah tersebut mendukung dan menyediakan kehidupan penduduk.

Problem tekanan penduduk dan ketersediaan lahan pertanian di tingkat makro dan meso sangat penting untuk dilihat relevansinya di tingkat mikro yaitu pada tingkatan komunitas petani di pedesaannya. Oleh karena itulah untuk selanjutnya tulisan ini mengambil komunitas Sedulur Sikep sebagai profil komunitas petani di tingkat mikro. Mengacu pada Pujiriyani dkk (2018), bayang-bayang deagrarianisasi secara nyata telah menyebabkan komunitas petani lebih dekat dengan berbagai aktivitas non pertanian yang tumbuh semakin eksklusif yang di satu sisi menegaskan bahwa hal ini menguatkan pernyataan bahwa keterbatasan daya dukung wilayah akan mendorong penduduk untuk mencari pekerjaan baru di luar sektor pertanian. Komunitas Sedulur Sikep sampai saat ini diketahui masih berteguh dengan pilihan hidup mereka sebagai petani karena secara internal komunitas mereka memiliki tatanan yang melarang untuk mengandalkan sumber nafkah di luar pertanian.

\section{Komunitas Sedulur Sikep dan Kepadatan Agrarisnya}

Komunitas Sedulur Sikep atau Samin merupakan salah satu komunitas petani yang berada di Desa Baturejo, sebuah desa persawahan yang berada di Kecamatan Sukolilo, Kabupaten Pati, Jawa Tengah. Sebagaimana disebutkan Rosyid (2008), istilah 'Samin' seringkali diplesetkan oleh masyarakat umum dengan kata 'nyamen' yang diidentikkan dengan perbuatan yang menyalahi 
kebiasaan. Istilah 'Samin' yang cenderung berkonotasi negatif inilah yang kemudian oleh para pengikutnya digeser dengan menamakan diri 'Sedulur Sikep'. Pada tahun 2018, jumlah komunitas Sedulur Sikep adalah 327 Kepala Keluarga (KK) atau 1089 jiwa yang terdiri dari 467 laki-laki dan 622 perempuan. Jumlah mereka ini secara keseluruhan sekitar 16,60\% dari keseluruhan warga Desa di Baturejo yang berjumlah 6557 jiwa. Komunitas Sedulur Sikep mendiami wilayah RW 1 Dukuh Bombong (Lihat Gambar 4). Selain Bombong, di Desa Baturejo terdapat 3 padukuhan lain yaitu Ronggo,Tempel, dan Bacem.

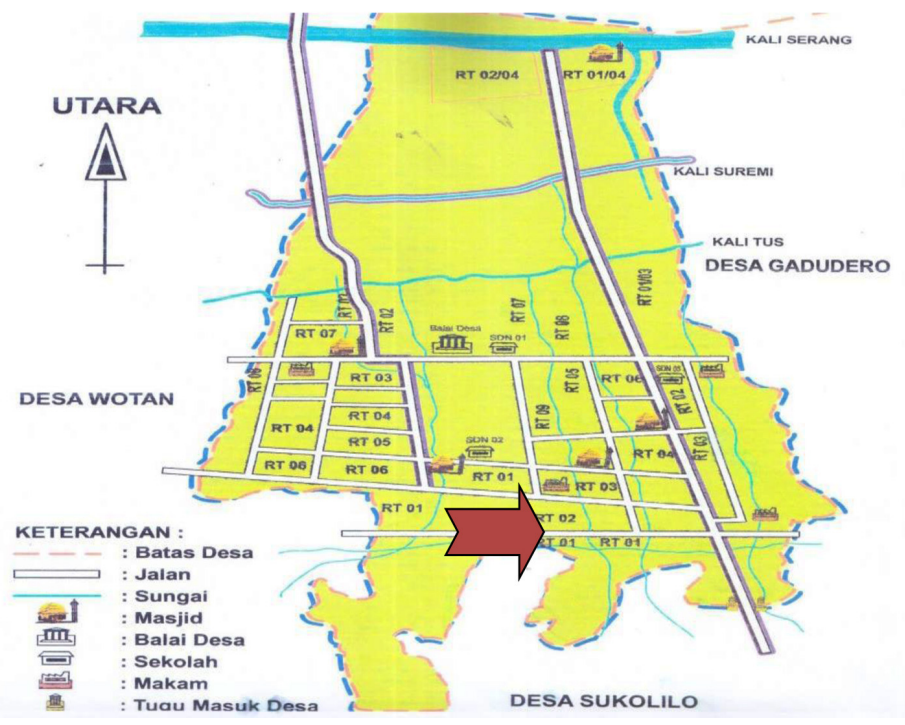

Gambar 4. Sketsa Peta Desa Baturejo.

Sumber: Dokumentasi Kantor Desa Baturejo.

Baturejo merupakan pusat wilayah dari Komunitas Sikep di Sukolilo. Dari aspek demografi, Desa Baturejo merupakan desa yang memiliki kepadatan penduduk tinggi. Dengan luas wilayah 10,24 km dan jumlah penduduk 6492 jiwa, desa ini memiliki kepadatan penduduk 640 jiwa $/ \mathrm{km}^{2}$. Angka ini jauh lebih tinggi daripada rata-rata kepadatan penduduk di Kecamatan Sukolilo yang sebesar 573 jiwa per $\mathrm{km}^{2}$ (BPS Kabupaten Pati 2018). Sebagai desa persawahan, ciri khas Desa Baturejo terlihat dari penggilingan padi (selepan) yang dengan mudah ditemukan serta jemuran gabah (padi) yang terhampar di halaman-halaman rumah beberapa warganya. Mesin-mesin pertanian seperti traktor dan perontok padi juga tampak diletakkan di teras atau bagian depan rumah. Lanskap persawahan memben- tang di sebelah utara pemukiman desa. Terdapat 830 hektar lahan persawahan yang terdiri 250 hektar sawah dengan irigasi teknis, 530 sawah dengan irigasi setengah teknis, dan 50 hektar sawah tadah hujan. Selain padi sawah, jagung, dan ketela pohon merupakan hasil pertanian yang cukup banyak ditanam oleh petani.

Pada tahun 2018, kepadatan agraris di Baturejo sebesar 532 jiwa $/ \mathrm{km}^{2}$ (Lihat Gambar 5). Angka ini lebih tinggi hampir 4 kali lipat daripada kepadatan agraris di Kabupaten Pati pada tahun 2018 yang tercatat sebesar 141 jiwa $/ \mathrm{km}^{2}$. Perbandingan antara luas lahan pertanian dengan jumlah petani di Desa Baturejo adalah sebesar 5 orang per hektar atau sekitar 0,2 ha per petani. Angka ini menunjukkan bahwa terdapat masalah kependudukanyang serius karena tersedianya tanah bagi masyarakat sangat terbatas. Banyak petani yang tidak memiliki lahan pertanian atau hanya menjadi buruh tani. Jumlah buruh tani di Desa Baturejo pada tahun 2018 adalah 1323 orang atau sekitar 26,15\% dari keseluruhan jumlah petani di Desa Baturejo.

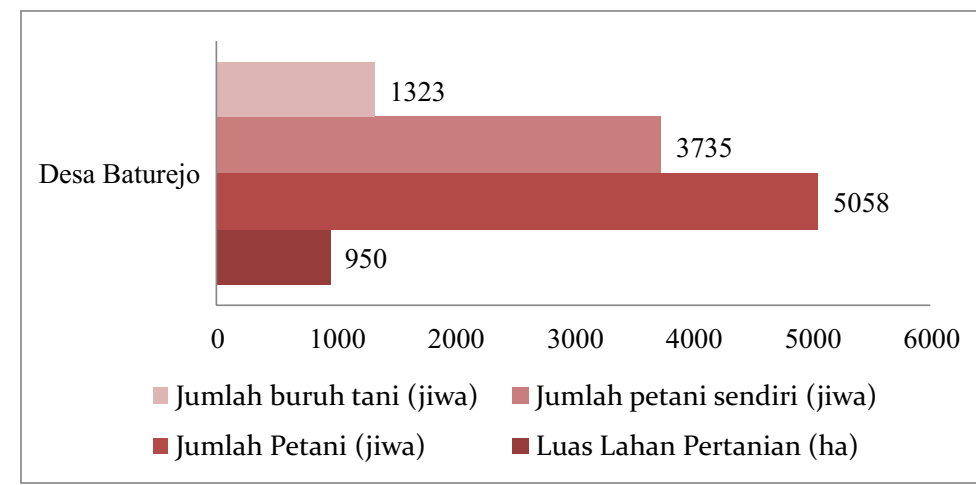

Gambar 5. Kepadatan Agraris Desa Baturejo 2018. Sumber: Diolah dari Monografi Desa Baturejo, Tahun 2018.

Ketimpangan antara jumlah petani dengan ketersediaan lahan pertanian juga dapat dicermati dari struktur pemilikan lahan. Sebagian besar petani di Desa Baturejo atau 73,01\%-nya termasuk dalam kategori petani gurem yaitu petani dengan kepemilikan lahan kurang dari o,26 hektar (Lihat Gambar 6). Sisanya adalah petani kecil dengan luasan lahan pertanian 0,26-o, 5 hektar yang berjumlah 20,06\%; petani menengah dengan kepemilikan lahan o,51-1 hektar yang berjumlah 5,6\%; dan petani kaya dengan kepemilikan lahan lebih dari 1 hektar yang berjumlah 1,31\%. 


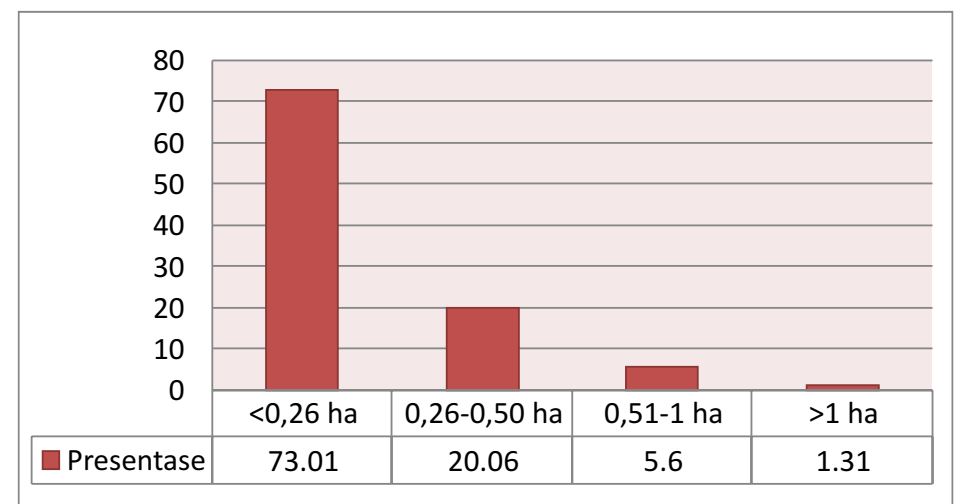

Gambar 6. Struktur Pemilikan Tanah Desa Baturejo.

Sumber: Diolah dari DKHP PBB Desa Baturejo, Sukolilo, Pati, Tahun 2018.

\section{Strategi Ekspansi: Menambah \\ Kepemilikan Lahan Pertanian}

Tekanan penduduk pada akhirnya mendorong penduduk khususnya petani untuk memperluas lahan garapannya atau keluar dari lapangan kerja pertanian (Ruhimat 2015). Pilihan yang pertama tampaknya menjadi pilihan yang dominan bagi komunitas Sedulur Sikep. Ketersediaan lahan di dalam lingkup internal komunitas, sudah tidak mencukupi. 'Kurang bebas' adalah istilah yang digunakan untuk menggambarkan bahwa Komunitas Sedulur Sikep perlu mencari alternatif tanah pertanian di luar lingkup komunitas (kampung) nya. “Tanah kampung mriki tanahe kurang bebas, wong tambahe wong rodo kadhuk, kulo kalih mbok wedok mawon tambah pitu. Mberah" (Tanah kampung di sini tanahnya tidak bebas, orang bertambah banyak, saya dengan istri saya saja punya anak 7) (Kn, petani, 56 tahun). Data kependudukan pada komunitas ini memang menunjukkan pertumbuhan yang sangat tinggi (Lihat Gambar 7). Pada tahun 2003 sampai dengan 2016, angka pertumbuhan penduduk pada Komunitas Sedulur Sikep per tahunnya mencapai 4,73\%. Jumlah warga Sedulur Sikep yang pada tahun 2003 berjumlah 633 jiwa, meningkat menjadi 1023 jiwa pada tahun 2016. Pada tahun 2018 jumlah ini meningkat kembali menjadi 1089 jiwa.

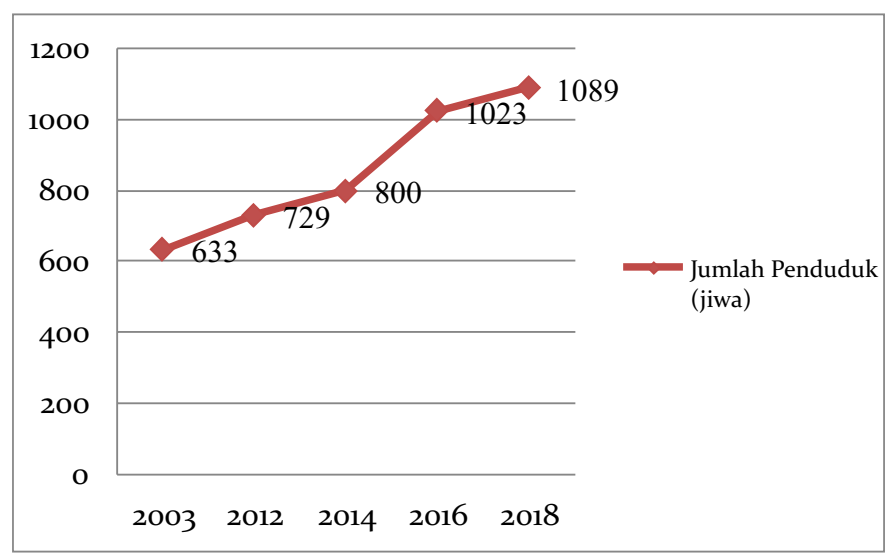

Gambar 7. Pertumbuhan Jumlah Anggota Komunitas Sedulur Sikep.

Sumber: Diolah dari berbagai sumber.

Ekspansi atau cara memperluas lahan pertanian dilakukan dengan membeli lahan pertanian yang ada di luar komunitas Sedulur Sikep. Desa Gadudero merupakan salah satu desa yang harga lahan pertaniannya masih cukup terjangkau. Harga yang terjangkau ini disebabkan karakter lahan pertanian yang semi rawa sehingga agak sulit untuk dikelola. Jika kisaran harga per 1 hektar di desa sekitarnya sudah mencapai 800 juta, maka di Desa Gadudero harganya relatif jauh lebih rendah sekitar setengahnya. Selain harga yang relatif jauh lebih rendah, Desa Gadudero juga dikenal sebagai desa yang memiliki tanah pertanian luas namun banyak warganya yang tidak berminat untuk mengolah lahan dan menjadi petani. Sumber nafkah yang lebih disukai oleh adalah berdagang. "Nek sedherek mriki, tanahe teng Gadu, ning nggih ijol (tuku). Nggen sederek mriko, ditumbas tiyang mriki." Dari membeli (ijol) tanah inilah, Komunitas Sedulur Sikep bisa menambah lahan-lahan pertanian yang dikelolanya. Tanah di wilayah Gadudero yang dikelola Sedulur Sikep bahkan mencapai 70\%.

Lahan bertambah, mergo dulur-dulur jiwane petani. Mulane akeh wong sikep garap sawah ning Gadu, itu mergo wong Gadu jiwa petanine, memang ora menurun tapi ora duwe jiwa petani. Wong Gadu...kan do ngepenake anak, tanahe do didol. Asale buruh, dadi dulur-dulur ki yo duwe sawah, yo mburuh. Lha ketika lahan sik digarap kui dijual, akeh sik dikuasai Sikep, hampir 7o\%. Tambah luas. Akeh lah sik ning Gadu. Garapanku sik ning Gadu yo kui asale nggon wong Gadu, tak tuku. (Komunikasi dengan Gr, petani, 49 tahun). 
Lahan bertambah karena Sedulur Sikep jiwanya petani. Makanya banyak warga Sikep yang menggarap sawah di Gadu (Desa Gadudero) karena orang Gadu jiwa petaninya memang tidak menurun, tidak punya jiwa petani. Orang Gadu kan memberikan kenyamanan ke anak, tanahnya dijual. Asalnya Sikep memang buruh, tapi meskipun buruh tetap punya sawah. Ketika lahan yang digarap itu dijual, banyak dikuasai Sikep, hampir 70\%. Tambah luas. Banyak yang di Gadu. Garapan saya yang di Gadu juga asalahnya milik orang Gadu, saya beli.

Meskipun kepadatan agraris dan tekanan penduduknya cukup tinggi, Komunitas Sedulur Sikep sangat optimis untuk bisa menambah luasan tanah pertanian dengan hasil panen yang mereka kumpulkan. "Simpenane duite saking mberahe, padahal tani tok, dilit-dilit tuku sawah." (Simpanan uangnya banyak, padahal cuma bertani, sebentar-sebentar membeli sawah). Kemampuan akumulasi secara ekonomi ini sangat mungkin dilakukan karena gaya hidup sehari-hari yang sederhana, sehingga menabung atau mengumpulkan 'koyo' menjadi sebuah prioritas dibandingkan menggunakannya untuk kebutuhan konsumtif.

Nek panenan setahun, dadinan, metunan, iso entuk 150 juta, iso tuku sawah. Panen melon kae entuk 6o juta. Yo bejan-bejan, nuju panen, pas regane larang (Komunikasi dengan Rs, 41 tahun).

Kalau panen setahun, panennya jadi, bagus, bisa dapat 150 juta, bisa beli sawah. Panen melon kemarin dapat 6o juta. Ya untung-untungan, kalau waktu panen, kebetulan pas harganya mahal.

Keberhasilan mereka bertani dan memelihara ternak membuat uang ratusan juta pun tidak mustahil untuk diperoleh. Dari uang yang dikumpulkan inilah mereka bisa membeli lahan pertanian (sawah) yang baru.

Nek dulur mriki ono sawah arep didol mesti dituku, gek mberu, mergo sapine mberu. Ono sik $1 / 4$ hektar, 111 juta. Biasane bar ngingoni sapi, sapine 6 nek 200 juta gampang. Nek menurut kono kan mligi tani tok ora bakal iso sukses, nek tani dinggo kecukupan saben dinone, nggo masak tok, blonjone yo luru-luru ngunduh jagung, nek kanggo sandang misale ngingoni sapi siji wis dadi pirang-pirang, wedus wis dadi pirangpirang. (Komunikasi dengan Rs, petani 41 tahun).

Kalau orang sini, ada sawah mau dijual pasti dibeli, dan banyak, karena sapinya juga banyak. Ada yang 1/4 hektar, 111 juta. Biasanya setelah memelihara sapi, sapinya punya 6 kan 200 juta mudah. Kalau menurut orang hanya bertani tidak bisa sukses, bertani untuk kecukupan sehari-hari, untuk masak saja, kalau belanja ya mencari yang lain, memanen jagung, kalau untuk simpanan ya memelihara sapi satu sudah jadi banyak, kambing juga bisa jadi banyak.

Kemampuan untuk membeli lahan ini salah satunya terlihat dari seorang anggota Komunitas Sedulur Sikep yang baru saja membeli lahan pertanian di Desa Gadudero seluas $\pm 2500 \mathrm{~m}^{2}$ dengan harga 200 juta rupiah pada tahun 2018 lalu.

Selain optimisme sebagai petani yang berhasil, jiwa petani juga merupakan salah satu alasan cukup agresifnya komunitas ini untuk menambah luas lahan pertaniannya. Jiwa petani yang dimiliki komunitas ini berbeda dengan jiwa petani yang dimiliki masyarakat di kampung sebelah yang sudah mulai tergerus (luntur). Komunitas Sedulur Sikep juga tidak menggunakan standar luasan minimal lahan pertanian seperti yang digunakan oleh masyarakat desa sekitarnya. Bagi Komunitas Sedulur Sikep, tidak ada standar kecukupan yang mereka khawatirkan dari luasan lahan pertanian yang dimiliki. Tidak ada kebutuhan 'mengirim anak ke lembaga pendidikan formal' yang seringkali dikeluhkan oleh komunitas non Sedulur Sikep sebagai kebutuhan hidupyang semakin memberatkan dari hari ke hari.

“...Wong ukuran sugih miskin kan teng pikiran, sik sugih nggih merasa kurang, sik sedengan ngaten niki nggih merasa cukup, wis kepenak, nrimo, ning panrimo. Ora ono ukuran sugih mlarat, ukurane ning nrimo. Wong akeh kurang akeh. Nek nrimo, sedeng ayem tentrem. Koyo wong sing duwe panenan akeh, angger rung trimo yo isih kurang. Ning nek duwe sitik, ning tansah cukup tak trimo, kuwi kudune..." (Komunikasi dengan St, petani, 34 tahun).

Ukuran kaya miskin itu di pikiran, yang kaya ya merasa kurang, yang sedang seperti ini sudah merasa cukup, sudah enak, menerima, di 
penerimaan. Tidak ada ukuran kaya miskin, ukurannya hanya penerimaan. Orang banyak, kurang banyak. Kalau menerima, sedangsedang saja sudah damai tentram. Seperti orang yang punya panen banyak, kalau belum menerima ya masih merasa kurang. Tapi kalau punya sedikit, tapi selalu menerima, itu yang seharusnya.

Bagi mereka sebisa mungkin tanah harus 'diuriuri' (dijaga dan dipelihara). Ada kebanggaan tersendiri ketika mereka yang awalnya hanya 'mburuh' (bekerja sebagai buruh tani) di sawah-sawah milik haji-haji yang kaya raya, pada akhirnya mampu membeli tanah itu.

Aku lak tuku 2 hektar. Biyen ijih murah, sawah 1 hektar 16 ewu, ning wis suwi 13 tahun biyen. Sak iki 1 hektar 350 juta, larang, nek ra wong gede, ra iso tuku. Nek rego 3o- rego 50 yo iso. Nek Sukolilo wong sugih-sugih, bolo kaji. Entek ning nggon wong kene kabeh ora ono sik keliwatan. Lemahe ditukoni wong kene kabeh. Duwe ning Gadu, tak tuku. Do duwe lemah didol, dituku wong kene. Anake wong sugih ora seneng tani, dinggo ngongkosi sekolah, nggo kaji. Aku ning rowo, kowe ameh ning ndi? Arep ning Gadu. Ora nuku sawahe kaji sik sukete dadi kae? Iyo arep nawake kui. Njaluk piro? Jaluk 20, wis 15 tak kei duit. Didol tenan. Ning duit 15 ki entuk grand 4 jaman biyen. Tuku nggon Kaji As, dikapling, dipetakpetak. Mantuku tuku 2 kapling 40 juta (Komunikasi dengan Ty, petani, 53 tahun).

Saya kan beli 2 hektar, dulu masih murah, sawah 1 hektar 16 ribu, tapi sudah lama 13 tahun yang lalu. Sekarang 1 hektar 350 juta, mahal, kalau bukan orang kaya, tidak bisa beli. Kalau harga 30-50 juta masih bisa. Kalau di Sukolilo tanah orang-orang kaya, haji-haji, tanahnya dibeli orang sini semua. Punya di Desa Gadudero saya beli. Banyak yang tanahnya dijual, dibeli orang sini. Anaknya orang kaya, tidak senang bertani, untuk membiayai sekolah, untuk naik haji. Saya waktu itu di sawah ditanya mau kemana? Mau ke Gadu. Tidak beli sawahnya pak Haji yang semaknya lebat itu? iya itu mau dijual, minta berapa? Minta 20, sudah 15 juta saya bayar. Dijual lah ke saya. Tapi uang 15 juta dulu bisa dapat motor bebek 4. Beli di Haji As, dikapling, dipetakpetak. Menantu saya beli 2 kapling 40 juta.

Lahan yang bisa dibeli oleh Komunitas Sedulur Sikep cukup bervariasi dari mulai o,1-2 hektar.
Kemampuan membeli lahan dengan luasan 2 hektar terjadi pada generasi kedua (sebelum tahun 2000), sementara itu pada tahun-tahun terakhir ini luasan lahan yang dibeli mulai berkurang karena harga lahan pertanian yang semakin mahal. Lahanlahan inilah yang kelak akan mereka berikan/ wariskan kepada anak-anaknya ketika sudah menikah untuk bisa melanjutkan aktivitas pertanian. Sampai saat ini (tahun 2019), aktivitas penambahan kepemilikan tanah, cukup efektif dalam menjaga rasio antara jumlah petani dengan ketersediaan lahan pertanian bagi Komunitas Sedulur Sikep khususnya untuk memastikan bahwa sampai generasi ke-4, mereka masih bisa memiliki luasan lahan pertanian yang memadai.

Salah satu contoh pemilikan lahan dalam 3 generasi Sedulur Sikep dapat dicermati dalam riwayat Keluarga Rj (Lihat Gambar 8). Rj adalah anak pertama dari 9 bersaudara. Generasi pertama keluarga Rj memiliki lahan pertanian seluas 4 hektar. Pada generasi kedua, luasan lahan ini berkurang. Masing-masing anak hanya menerima warisan dari Jy seluas o,5 hektar. Namun lahan pertanian pada akhirnya bertambah kembali karena $\mathrm{Wj}$, salah satu anak Rj bisa membeli lahan seluas 2 ha, sehingga Wj sebagai generasi kedua bisa memiliki lahan seluas 2,5 hektar. Selanjutnya pada generasi ketiga, kepemilikan lahan pertanian kembali berkurang. Rj menerima lahan pertanian dari Wj seluas o,25 hektar. Setelah menikah Wj bisa membeli lahan seluas o,35 hektar, sehingga luas lahan yang dimilikinya ditambah dengan lahan dari istrinya secara keseluruhan menjadi o,85 hektar.

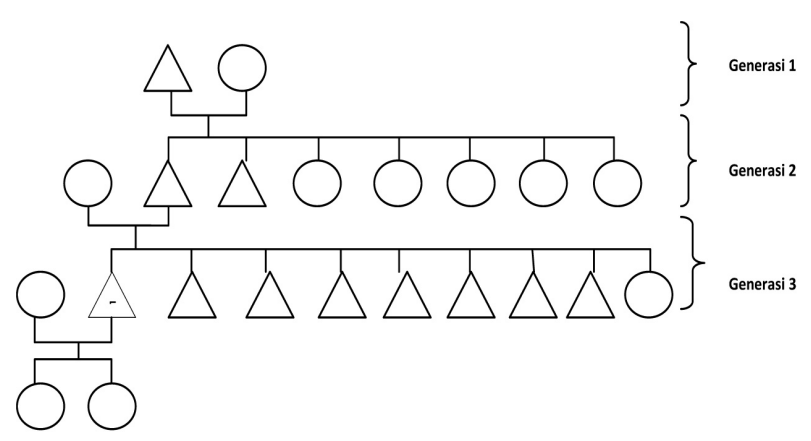

Gambar 8. Garis Kekerabatan 3 Generasi Keluarga Rj. Sumber: Data primer, 2019. 
Alur 3 generasi dalam Keluarga Rj menunjukkan kemampuan generasi yang lebih muda untuk tidak hanya mengandalkan lahan pertanian pemberian orang tuanya, tetapi juga menambah lahan pertanian sendiri dengan cara membelinya. Meskipun luasannya semakin berkurang (semakin sempit) dan tidak lagi semudah generasi pertama dan kedua dalam memperoleh lahan pertanian yang baru, generasi ke-3 masih memiliki peluang untuk menambah lahan pertanian dari adanya penjualan lahan pertanian di desa sekitarnya. Penambahan lahan inilah yang menjadi jaminan kepemilikan lahan bagi generasi-generasi yang lebih muda.

\section{E. Strategi Populasi: Mengurangi Jumlah Keluarga Inti (Nuclear Family)}

Selain aktivitas penambahan kepemilikan tanah, perubahan ukuran keluarga inti juga mendukung rasio bentang agraris dengan jumlah petani. Keluarga inti Komunitas Sedulur Sikep saat ini memang sudah berbeda dengan keluarga inti Komunitas Sedulur Sikep di masa lalu. Jika dahulu keluarga inti Sedulur Sikep bisa terdiri dari 11-12 anggota keluarga karena jumlah anak dalam keluarga inti yang bisa mencapai 7-9, maka saat ini ukuran keluarga inti (nuclear family) Komunitas Sedulur Sikep jauh lebih kecil dengan rata-rata jumlah anak 1-2 orang (lihat Tabel 2).

Tabel 2. Jumlah Anak dalam Keluarga Inti Komunitas Sedulur Sikep

\begin{tabular}{clccccc}
\hline No. & Nama Kepala & Tahun & \multicolumn{4}{c}{ Jumlah Anak } \\
\cline { 5 - 7 } & Keluarga & Lahir & 1 & 2 & 3 & $>3$ \\
\hline 1 & Sutiyon & 1981 & & v & & \\
2 & Sutrisno & 1976 & v & & & \\
3 & Kisnandar & 1978 & & v & & \\
4 & Yono & 1985 & v & & & \\
5 & Andi & 1988 & v & & & \\
6 & Toyo & 1982 & & v & & \\
7 & Pranoto & 1987 & v & & & \\
8 & Jasminto & 1984 & & v & & \\
9 & Saryono & 1983 & & & v & \\
10 & Hardi & 1987 & v & & & \\
11 & Domo & 1984 & v & & & \\
12 & Kumbino & 1977 & & v & & \\
13 & Sumari & 1957 & & & & V \\
14 & Maseran & 1960 & & & & v \\
15 & Rusdi & 1971 & & & & \\
16 & Asing & 1975 & & & v & \\
17 & Sundoko & 1985 & v & & & \\
18 & Saparin & 1970 & & v & &
\end{tabular}

\begin{tabular}{clccccc}
\hline No. & Nama Kepala & Tahun & \multicolumn{5}{c}{ Jumlah Anak } \\
\cline { 5 - 7 } & Keluarga & Lahir & 1 & $\mathbf{2}$ & 3 & $>3$ \\
\hline 19 & Darmadi & 1970 & & V & & \\
20 & Gariyo & 1970 & & & v & \\
21 & Saryono & 1974 & & & v & \\
22 & Hardi & 1987 & v & & & \\
23 & Cito & 1984 & v & & & \\
24 & Suwito & 1978 & v & & & \\
25 & Sutono & 1977 & v & & & \\
\hline Jumlah & & 11 & 7 & 4 & 3 \\
\hline Persentase & & $44 \%$ & $28 \%$ & $16 \%$ & $12 \%$ \\
\hline
\end{tabular}

Sumber: Data Kependudukan Desa Baturejo, Tahun 2017.

Menurunnya jumlah keluarga inti bukan semata disebabkan oleh masuknya program Keluarga Berencana yang mulai diterima, tetapi lebih karena Komunitas Sedulur Sikep menyadari bahwa memiliki banyak anak juga memberikan tanggungjawab yang lebih besar untuk bisa mencukupi kebutuhannya, "Anak akeh, nglantarke sandang pangan juga akeh (anak banyak, kebutuhan sandang pangan juga banyak). Sebagian besar Komunitas Sedulur Sikep di Desa Baturejo justru bersikap apatis terhadap program Keluarga Berencana (KB). Mereka tidak menolak dan juga tidak menerima program KB. Oleh karena itulah sebagian besar dari mereka tidak mengikuti program KB. Mereka memiliki cara sendiri untuk mengurangi jumlah anak. Hanya sebagian kecil saja yang mengikuti program KB. Suprihatini (2014) mencatat bahwa ada sekitar 17 anggota Komunitas Sedulur Sikep yang mengikuti program KB. Program ini diikuti setelah ada sedikit pemaksaan dari aparat desa setempat. KB dengan suntik merupakan jenis KB yang selama ini mereka ikuti. Jumlah anak dalam keluarga yang mulai berkurang merupakan mekanisme pengendalian yang secara tidak langsung menjaga lahan-lahan pertanian tetap mampu mencukupi kebutuhan komunitas Sedulur Sikep yang secara nyata menegaskan dirinya sebagai petani murni sepenuhnya (mligi tani).

\section{F. Kesimpulan}

Tekanan penduduk terhadap lahan pertanian merupakan dampak nyata dari pertambahan jumlah penduduk. Pertumbuhan populasi menyebabkan plot tanah yang dikelola petani menjadi semakin berkurang. Jumlah penduduk semakin bertambah dari waktu ke waktu, sebaliknya jumlah lahan 
pertanian justru semakin berkurang dari waktu ke waktu. Tekanan penduduk akan mendorong petani untuk memperluas lahan garapannya atau keluar dari lapangan kerja pertanian.

Komunitas Sedulur Sikep menunjukkan bahwa komunitas agraris tidak akan meninggalkan pertanian dengan mudahnya meskipun terjadi tekanan penduduk. Hal ini menunjukkan bahwa tesis yang diajukan Muyanga \& Jaine (2014) bahwa tekanan penduduk akan menyebabkan petani keluar dari pertanian, tidak terjadi. Komunitas Sedulur Sikep tetap bertahan dan secara aktif berupaya untuk bisa terus mengelola lahan pertanian dan bisa mewariskannya kepada generasi berikutnya. Mereka memilih untuk memanfaatkan peluang dari komunitas di sekitarnya yang sudah mulai kehilangan minat untuk mengelola tanah pertanian. Optimisme menambah kepemilikan lahan pertanian bagi generasi yang lebih muda dilakukan dengan cara membeli lahan pertanian dari mereka yang sudah tidak berminat menekuni pertanian.

Selain berupaya menambah lahan pertanian, Komunitas Sedulur Sikep juga menyadari sepenuhnya bahwa daya dukung lingkungan mereka berkurang karena jumlah anak-anak yang bertambah. Oleh karena itulah, pilihan untuk membatasi jumlah anak dalam keluarga inti juga dilakukan. Hal ini bertujuan untuk mengurangi beban yang harus ditanggung untuk mencukupi kebutuhan pangan mereka sehari-hari.

\section{Daftar Pustaka}

Ashari 2003, 'Tinjauan tentang alih fungsi lahan sawah ke non sawah dan dampaknya di Pulau Jawa', Forum Penelitian Ekonomi, vol. 21, no. 2, hlm. 83-98.

Bachriadi, D dan Wiradi, G 2011, Enam dekade ketimpangan: masalah penguasaan tanah di Indonesia, Agrarian Resourse Centre, Bina Desa dan Konsorsium Pembaruan Agraria, Bandung.

Berg, BL 2001, Qualitative research methods for social sciences, Allyn and Bacon, United States.

Bryceson, D 2002, 'Multiplex livelihoods in rural Africa: recasting the terms and conditions of gainful employment', Journal of Modern African Studies, vol. 40, no. 1, hlm. 1-28. doi: 10.1017/30022278x01003792.

Badan Pusat Statistik, Statistik Indonesia 2018, Badan Pusat Statistik, Jakarta.

Badan Pusat Statistik Pati, Kecamatan Sukolilo Dalam Angka 2018, Badan Pusat Statistik, Pati. Badan Pusat Statistik Provinsi Jawa Tengah, 2018, Jawa Tengah Dalam Angka, Badan Pusat Statistik, Jawa Tengah. 2013, Laporan Hasil Sensus Pertanian 2013 (Pencacahan Lengkap), Badan Pusat Statistik, Jawa Tengah.

Effendi, PML dan Asmara, A 2014, 'Dampak pembangunan insfrastruktur jalan dan variabel ekonomi lain terhadap luas lahan sawah di koridor ekonomi Jawa', Jurnal Agribisnis Indonesia, vol. 2, Juni, hlm. 21-32.

Geertz, C 1983, Involusi pertanian proses perubahan ekologi di Indonesia, Lembaga Penelitian Sosiologi Pedesaan IPB dan Yayasan Obor Indonesia, Jakarta.

Hakim, M, Wiratno, O, Abdurachman, AA 2017, Statistik lahan pertanian tahun 2012-2016, Pusat Data dan Sistem Informasi Pertanian, Sekretariat Jenderal, Kementerian Pertanian, Jakarta.

Hakim M, Wiratno, O, Abdurachman, AA 2018, Statistik lahan pertanian tahun 2013-2017, Pusat Data dan Sistem Informasi Pertanian, Sekretariat Jenderal, Kementerian Pertanian, Jakarta.

Headye, D, Dereje, M, Taffesse, AS 2014, 'Land constraints and agricultural intensification in Ethiopia: a village-level analysis of high-potential areas', Food Policy 48, hlm. 129-141.

Latruffe, L, Piet L 2013, 'Comparative analysis of factor markets for agriculture across the member states', Working Paper, no. 40, April, hlm. 1-22.

Long, N 2001, Development sociology: actor perspectives, UK: Routledge, London.

Manjunatha, AV, Anik, AR, Speelman, S, Nuppenau, EA 2013, 'Impact of land fragmentation, farm size, land ownership and crop diversity on profit and efficiency of irrigated farms in In- 
dia', Land Use Policy, 31, hlm. 397-405. http:// dx.doi.org/10/1016/j.landusepol.2012.08.005.

Mellor, JW 2014, 'High rural population density Africa-whatare the Growth Requirements and who participates?', Food Policy 48, hlm. 6675.

Molle, F, Srijantr, T 2003, 'Between concentration and fragmentation the resilience of the land system in the Chao Phraya Delta', In Molle, F and Srijantr, eds. Thailand Rice Bowl: Perspectives on Social and Agricultural Change in the Chao Praya Delta, White Lotus, Bangkok.

Muyanga, M, Jayne, TS 2014, 'Effects of rising rural population density on smallholder agriculture in Kenya', Food Policy 48, hlm. 98-113.

Ploeg, J 2008, The new peasantries struggles for autonomy and sustainability in era of era of empire and globalization, Earthscan Publisher, UK.

Pujiriyani, DW, Soetarto, E, Santosa, DA, Agusta, I 2018, 'Deagrarianisasi dan dislokasi nafkah di pedesaan Jawa', Sodality, vol 6, no. 2, Agustus, hlm. 137-145.

Ricker-Gilbert, J, Jumbe, C, Chamberlin, J 2014, 'How does population density influence agricultural intensification and productivity? Evidence from Malawi', Food Policy 48, hlm. 114128.
Rigg, J 2001, 'Embracing the global in Thailand: activism and pragmatism in an era of deagrarianization', World Development, vol 29, no. 6, hlm. 945-960.

Rohman, MN, Hayati, R 2015, 'Analisis tekanan penduduk agraris Provinsi Jawa Tengah tahun 2020', Geo Image (1), hlm. 1-8.

Rosyid, M 2008, Samin Kudus: bersahaja di tengah asketisme lokal, Pustaka Pelajar, Yogyakarta.

Ruhimat, M 2015, 'Tekanan penduduk terhadap lahan di Kecamatan Sukaraja Kabupaten Sukabumi', Gea-Jurnal Pendidikan Geografi, vol. 15, no. 2, hlm. 59-65.

Suprihatini, T 2014, 'Penerimaan masyarakat samin terhadap program pembangunan di Desa Baturejo, Kecamatan Sukolilo, Kabupaten Pati, Jawa Tengah'. Jurnal Ilmu Sosial, vol. 13, no.2, hlm. 77-85.

Tauchid, M 2009, Masalah agraria sebagai masalah penghidupan dan kemakmuran rakyat Indonesia, STPN Press, Yogyakarta.

Tjondronegoro, S, Wiradi, G 2008, Dua abad penguasaan tanah: pola penguasaan tanah pertanian di Jawa dari masa ke masa, Yayasan Obor Indonesia, Jakarta.

United Nations, 2015, World population projected to reach 9.7 Billion by 2050, www.un.org. Diakses 9 Maret 2019. 